ORIGINAL ARTICLE

\title{
Vildagliptin Ameliorates Oxidative Stress and Pancreatic Beta Cell Destruction in Type 1 Diabetic Rats
}

\author{
Danielle de Lima Ávila, ${ }^{a}$ Glaucy Rodrigues de Araújo, ${ }^{a}$ Maisa Silva, ${ }^{\text {a }}$ \\ Pedro Henrique de Amorim Miranda, ${ }^{\mathrm{a}}$ Mirla Fiuza Diniz, ${ }^{\mathrm{a}}$ Maria Lúcia Pedrosa, a,b \\ Marcelo Eustáquio Silva, ${ }^{\mathrm{a}, \mathrm{c}}$ Wanderson Geraldo de Lima, ${ }^{\mathrm{a}, \mathrm{b}}$ and Daniela Caldeira Costa ${ }^{\mathrm{a}, \mathrm{b}}$ \\ ${ }^{\mathrm{a}}$ Núcleo de Pesquisas em Ciências Biológicas-NUPEB, ${ }^{\mathrm{b}}$ Departamento de Ciências Biológicas, Instituto de Ciências Exatas e Biológicas, ${ }^{\mathrm{c}}$ Departamento de \\ Alimentos, Escola de Nutrição, Universidade Federal de Ouro Preto, Ouro Preto, Brazil
}

Received for publication August 21, 2012; accepted March 5, 2013 (ARCMED-D-12-00436).

\begin{abstract}
Background and Aims. It is believed that oxidative stress plays a role in the pathogenesis of diabetes mellitus. Several strategies have been developed with the objective of minimizing diabetic complications. Among these, inhibitors of dipeptidyl peptidase-IV (DPP-IV), which act by blocking degradation of incretin hormones, glucagon-like peptide hormone (GLP-1) and glucose-dependent insulinotropic polypeptide (GIP), have been the focus of many studies. It is known that, among the effects of incretins, we highlight its insulinotropic and cytoprotective effects on pancreatic $\beta$-cells. The objective of this study was to evaluate the possible protective effects of treatment with vildagliptin, a DPP-IV inhibitor, in $\beta$-cells in an experimental model of type 1 diabetes induced by streptozotocin (STZ).

Methods. Rats were treated for 4 weeks with vildagliptin at concentrations of 5 and 10 $\mathrm{mg} / \mathrm{kg}$. In order to observe the pancreatic damage and the possible protective effects of vildagliptin treatment, we measured stress markers TBARS and protein carbonyl, antioxidant enzymes SOD and catalase, and analyzed pancreatic histology.

Results. The treatment was effective in modulating stress in pancreatic tissue, both by reducing levels of stress markers as well as by increasing activity of SOD and catalase. After analyzing the pancreatic histology, we found that vildagliptin was also able to preserve islets and pancreatic $\beta$-cells, especially at the concentration of $5 \mathrm{mg} / \mathrm{kg}$.

Conclusion. Thus, our results suggest that vildagliptin ameliorates oxidative stress and pancreatic beta cell destruction in type 1 diabetic rats. However, to evaluate the real potential of this medication in type 1 diabetes, further studies are needed. (C) 2013 IMSS. Published by Elsevier Inc.
\end{abstract}

Key Words: Inhibitor DPP-IV, Pancreas, Oxidative stress, Antioxidant.

\section{Introduction}

Despite substantial advances in our understanding of type 1 diabetes, diagnosis of the condition still requires lifelong daily insulin injections, which are a partially effective therapy at best (1). New therapeutic strategies under investigation include islet transplantation, development of

Address reprint requets to: Daniela Caldeira Costa, Universidade Federal de Ouro Preto, Campus Universitario Morro do Cruzeiro, Ouro Preto, Brazil; Phone: $(+55) 31$ 3559-1761; FAX: $(+55) 31$ 3559-1680; E-mail: dani.caldeiracosta@gmail.com improved insulin analogues and delivery systems, gene therapy, and the search for novel agents that can protect and/or stimulate the proliferation and regeneration of islet $\beta$-cells (1). The importance of the latter strategy is underscored by the need for an inexpensive, benign, preventive therapy that lacks the considerable side effects of most therapies studied to date (e.g., immunosuppressants) (2). In this context, glucose-dependent insulinotropic polypeptide (GIP) and glucagon-like peptide-1 (GLP-1) are gastrointestinal hormones that potentiate glucosestimulated insulin secretion and are classified as incretins. Additionally, these incretins stimulate both insulin 
biosynthesis and proliferation of $\beta$-cells while inhibiting apoptosis (3-7). Dipeptidyl peptidase-IV (DPP-IV) terminates the actions of GIP and GLP-1 (8-10). DPP-IV is a multifunctional glycoprotein that contains NH2-terminal serine dipeptidase activity and is present in circulation and on the cell surface (11). Relatively few studies have been conducted on the potential for DPP-IV inhibitors (DPP-IVi) in the treatment of type 1 diabetes. In preclinical studies, the DPP-IVi isoleucine thiazolidine improved glucose tolerance in streptozotocin (STZ)-induced diabetic rats $(2,12)$, with clear islet protection in the former group (2). The effect of DPP-IVi on $\beta$-cells may be small because the destruction of $\beta$-cells leads to absolute insulin deficiency by cellmediated autoimmune attack. Additionally, a recent report showed that DPP-IV may ameliorate an autoimmune attack against $\beta$-cells by restoring or increasing the number of regulatory $\mathrm{T}$ lymphocytes. Altogether, incretin-based therapy may be worth testing in patients with type 1 diabetes (13). It has been reported that the DPP-IVi sitagliptin not only improves glucose metabolism but also protects $\beta$-cells, promotes islet neogenesis, and prolongs islet graft survival in rodent diabetic models $(2,14,15)$. Furthermore, DPP-IVi have been reported to delay or suppress the occurrence of hyperglycemia in an animal model of spontaneous diabetes (16), but the mechanisms have not been completely elucidated. Hyperglycemia leads to cellular damage and organ dysfunction (17). In the pancreas, chronic hyperglycemia produces progressive deleterious effects on $\beta$-cells $(18,19)$, which are manifested by increased oxidative stress $(20,21)$. Thus, one of the factors that contributes to pancreatic dysfunction is oxidative stress (22). Pancreatic $\beta$-cells are vulnerable to oxidative stress due to the low antioxidant enzyme activities $(23,24)$, and enhancing antioxidant defense mechanisms in pancreatic islets helps these cells cope with oxidative stress. Thus, if treatments with DPP-IV modulate oxidative stress in the pancreas, then these treatments can be used to reduce oxidative damage, thus minimizing diabetes-associated complications. In the present study, our objective was to evaluate the parameters of oxidative stress and antioxidant enzymes in the pancreas of type 1 diabetic rats treated with vildagliptin, a DPP-IVi.

\section{Materials and Methods}

\section{Reagents}

The chemical reagents, including STZ (streptozotocin), 2,4-dinitrophenylhydrazine (DNPH) and thiobarbituric acid (TBA), were purchased from Sigma-Aldrich (St. Louis, MO).

\section{Animals}

Eleven-week-old female Fisher rats weighing $\sim 180 \mathrm{~g}$ were obtained from the Laboratory of Experimental Nutrition, Escola de Nutrição, Universidade Federal de Ouro Preto. During the experimental period, the animals were kept in a well-ventilated environment with controlled temperature, humidity and ventilation. Animals had access to water and commercial rat rations ad libitum. This study was conducted in accordance with the international standards of animal protection and the ethical principles of the Brazilian College of Animal Experimentation (25) and was approved by the Ethics Committee on Animal Use (CEUA) of UFOP (protocol 2011/27).

At the beginning of the experiment, animals showed similar glucose levels. Animals were randomly assigned to a normal control or diabetes group. Age-matched normal control rats were injected with an equal volume of vehicle (sodium citrate buffer).

Forty-eight rats were distributed into six groups according to the treatment they received: untreated control group (C), control group treated with $5 \mathrm{mg} / \mathrm{kg}$ vildagliptin (C5), control group treated with $10 \mathrm{mg} / \mathrm{kg}$ vildagliptin (C10), untreated diabetic group (D), diabetic group treated with $5 \mathrm{mg} / \mathrm{kg}$ vildagliptin (D5), and diabetic group treated with $10 \mathrm{mg} / \mathrm{kg}$ vildagliptin (D10). Three days after diabetes was induced, vildagliptin was administered by gavage for 30 days. Vildagliptin (Novartis), a DPP-IVi, was commercially acquired and diluted in phosphate buffer suspended in $0.05 \%$ of methylcellulose in a final concentration of 5 or $10 \mathrm{mg} / \mathrm{kg}$ body weight/day (26). The vildagliptin dosages used were based on the literature (27-31).

\section{Diabetes Induction}

We used streptozotocin (STZ) to induce an experimental model of type 1 diabetes. STZ is the most prominent diabetogenic chemical in diabetes research and is a cytotoxic glucose analogue. STZ inhibits insulin secretion and causes a state of insulin-dependent diabetes mellitus. Both effects can be attributed to the specific chemical properties of STZ, namely, its alkylating potency. $\beta$-cell specificity is primarily the result of selective cellular uptake and accumulation. Streptozotocin enters the $\beta$-cell via a glucose transporter (GLUT2) and causes alkylation of DNA (32).

We treated rats i.p. with $35 \mathrm{mg} / \mathrm{kg}$ of STZ dissolved in $0.2 \mathrm{~mL}$ citrate buffer $(0.01 \mathrm{M}, \mathrm{pH} 4.5)$. Diabetes was verified $72 \mathrm{~h}$ later by evaluating blood glucose levels using Accu-Chek active (Roche Laboratories, San Francisco, CA). After overnight fasting, a blood glucose level of 300 $\mathrm{mg} / \mathrm{dL}$ was used to establish diabetes.

\section{Insulin}

Serum insulin levels were determined using a commercial kit from Crystal Chem Inc (Downers Grove, IL). Using the sandwich ELISA method, this kit is sensitive for determination of insulin in rats.

\section{Preparation of Pancreatic Tissue}

Pancreatic tissue was collected immediately after animals were euthanized. To determine the carbonyl protein 
concentrations, $200 \mathrm{mg}$ of tissue was homogenized in 50 mmol phosphate buffer (pH 6.7) and 1 mmol EDTA. To determine the concentration of thiobarbituric acid reactive substances (TBARS), superoxide dismutase and catalase activity, $100 \mathrm{mg}$ of pancreatic tissue was homogenized in phosphate buffer ( $\mathrm{pH} 7.4)$. After homogenization, samples were centrifuged at $10,000 \times \mathrm{g}$ for $10 \mathrm{~min}$ at $4^{\circ} \mathrm{C}$. The supernatant was collected and used as the biological sample.

\section{Determination of Antioxidant Defenses}

Catalase (CAT). Catalase activity was determined based on its ability to convert hydrogen peroxide $\left(\mathrm{H}_{2} \mathrm{O}_{2}\right)$ into water and molecular oxygen. Assays were performed as described by Aebi (33). Briefly, $10 \mu \mathrm{L}$ of sample supernatant was mixed with $50 \mu \mathrm{L}$ of $\mathrm{K}_{2} \mathrm{HPO}_{4}, 40 \mu \mathrm{L}$ of milli-Q water (Millipore, Bedford, MA) and $900 \mu \mathrm{L}$ of $2.5 \mathrm{mmol} / \mathrm{L}$ $\mathrm{H}_{2} \mathrm{O}_{2}$ before being spectrophotometrically measured at $240 \mathrm{~nm}$ at $25^{\circ} \mathrm{C}$. Concentrations of $\mathrm{H}_{2} \mathrm{O}_{2}$ and samples were chosen so that the degradation rate was linearly proportional at $30 \mathrm{sec}, 1 \mathrm{~min}, 2 \mathrm{~min}$ and $3 \mathrm{~min}$. One unit (U) of catalase is equivalent to the hydrolysis of $1 \mu \mathrm{mol}$ of $\mathrm{H}_{2} \mathrm{O}_{2} /$ min.

Superoxide dismutase activity (SOD). Total superoxide dismutase (SOD) activity was measured by the kit from Cayman Chemical Company (Ann Arbor, MI). Briefly, pancreatic cells were homogenized in cold $20 \mathrm{mmol}$ HEPES, pH 7,2, containing $1 \mathrm{mmol}$ EGTA, $210 \mathrm{mmol}$ mannitol and $70 \mathrm{mM}$ sucrose. Ten $\mu \mathrm{L}$ of supernatant was used in the test. The reaction was initiated by adding xanthine oxidase. The plate was incubated on a shaker for $20 \mathrm{~min}$ at room temperature, and the absorbance was measured at $450 \mathrm{~nm}$ using a plate reader (Biotek ELx808, Green Mountains of Vermont).

\section{Determination of Oxidative Stress Markers}

Thiobarbituric acid reactive substances (TBARS). TBARS concentration was determined from thiobarbituric acid (TBA) binding to oxidized lipids. This measurement was performed according to Buege and Aust (34). Briefly, 250 $\mu \mathrm{L}$ of $28 \%$ trichloroacetic acid (TCA) was added to 500 $\mu \mathrm{L}$ of sample supernatant, $250 \mu \mathrm{L}$ of TBA (1\% in acetic acid 1:1) and $125 \mu \mathrm{L}$ of butylated hydroxytoluene (BHT) (5 mmol in ethanol). Samples were then incubated at $95^{\circ} \mathrm{C}$ for $15 \mathrm{~min}$. The mixture was subsequently centrifuged at $10,000 \mathrm{~g}$ for $15 \mathrm{~min}$. Supernatant absorbance was measured at $535 \mathrm{~nm}$ using a spectrophotometer. Values were expressed in $\mathrm{nmol} / \mathrm{mg}$ of protein.

\section{Carbonylated Protein}

Protein oxidation by ROS leads to the formation of carbonyl derivatives, which can be measured by sensitive methods. Methods that use 2,4-dinitrophenylhydrazine (DNPH), which reacts with carbonyl groups to generate the corresponding hydrazone and can then be analyzed spectrophotometrically, are especially useful. Measurements of carbonylated protein were performed according to Levine et al. (35). In brief, proteins were precipitated using TCA (10\%) and incubated with DNPH and $\mathrm{HCl}$ at room temperature for $30 \mathrm{~min}$. TCA $(10 \%)$ was added to the precipitate and centrifuged at $5,000 \times \mathrm{g}$ for $5 \mathrm{~min}$ at $4^{\circ} \mathrm{C}$. After discarding the supernatant, the precipitate was washed twice with ethanol/ethyl acetate (1:1), dissolved in $6 \%$ sodium dodecyl sulfate (SDS) solution and centrifuged at $10,000 \times \mathrm{g}$ for $10 \mathrm{~min}$ at $4^{\circ} \mathrm{C}$. Supernatant absorbance was measured at $370 \mathrm{~nm}$ using a spectrophotometer. Results were expressed as nmol of carbonyl groups $/ \mathrm{mg}$ of protein.

\section{Histological Evaluation}

Pancreas fragments not exceeding $4 \mathrm{mmol}$ in diameter were fixed in $10 \%$ formaldehyde solution and then dehydrated, diaphonized and embedded in paraffin. Paraffin sections of $\sim 4 \mu \mathrm{m}$ were obtained by sectioning embedded fragments on a rotary microtome. Sections were mounted on cleaned and degreased glass slides. The slides were stained with hematoxylin and eosin for visualization of histological damage and Gomori's trichrome to differentiate phenotypes of pancreatic beta and alpha cells. To determine the average number of inflammatory cells as well as the average size and area of pancreatic islets, digital morphometric analyses were performed using a Leica optical microscope with the Leica Qwin Plus analysis software DM5000 (Leica Microsystems, Buffalo Grove, IL). The average number of beta and alpha cells was determined using ImageJ software (NIH, Bethesda, MD).

All histological samples from the control and treatment animals underwent blind analysis.

\section{Statistical Analysis}

All values are expressed as mean \pm SD. Statistical analysis was performed using unpaired Student $t$ test for betweengroup comparisons. One-way ANOVA with Tukey posttest was used for analysis between all groups. GraphPad Prism v.5.0 software was used for the analysis; $p<0.05$ was considered statistically significant.

\section{Results}

\section{Evaluation of Body Weight, Blood Glucose and Plasma} Insulin Levels

As shown in Table 1, no significant differences were found in the initial weight between the control and diabetic groups. However, we observed a significant reduction in the final weight of the animals in the diabetic 
Table 1. Evaluation of body weight, blood glucose and plasma insulin levels

\begin{tabular}{|c|c|c|c|c|c|c|}
\hline Experimental groups & $\mathrm{C}$ & C5 & $\mathrm{C} 10$ & $\mathrm{D}$ & D5 & D10 \\
\hline Initial weight (g) & $182.2 \pm 22.4$ & $183.4 \pm 18.1$ & $182.4 \pm 8.9$ & $178.2 \pm 7.5$ & $180.0 \pm 10.5$ & $180.6 \pm 8.6$ \\
\hline Final weight $(\mathrm{g})$ & $215.2 \pm 19.5$ & $217.2 \pm 15.6$ & $212.6 \pm 10.2$ & $154.8 \pm 18.9^{\mathrm{a}}$ & $168.1 \pm 23.2^{\mathrm{b}}$ & $153.8 \pm 19.1^{\circ}$ \\
\hline Initial glycemia (mg/dL) & $92.2 \pm 22.3$ & $87.7 \pm 10.6$ & $101.0 \pm 17.7$ & $403.7 \pm 79.5^{\mathrm{a}}$ & $375.5 \pm 13$ & $357.1 \pm 76.9$ \\
\hline Final glycemia (mg/dL) & $88.3 \pm 16.4$ & $87.7 \pm 10.3$ & $97.7 \pm 13.2$ & $389.7 \pm 88.5^{\mathrm{a}}$ & $357.8 \pm 159.6$ & $322.9 \pm 93.1$ \\
\hline Insulin $(\mathrm{pmol} / \mathrm{L})$ & $56.8 \pm 11.2$ & $50.7 \pm 11.7$ & $52.2 \pm 14.9$ & $11.6 \pm 8.7^{\mathrm{a}}$ & $34.3 \pm 8.0^{\mathrm{b}, \mathrm{d}}$ & $32.2 \pm 8.9^{\mathrm{c}, \mathrm{c}}$ \\
\hline
\end{tabular}

$\mathrm{C}$, control (untreated); $\mathrm{C} 5$, control $+5 \mathrm{mg}$ vildagliptin $\cdot(\mathrm{kg} \text { body mass })^{-1} ; \mathrm{C} 10$, control $10 \mathrm{mg}$ vildagliptin $\cdot\left(\mathrm{kg}\right.$ body mass) ${ }^{-1} ; \mathrm{D}$, diabetic; D5, diabetic +5 $\mathrm{mg}$ vildagliptin $\cdot(\mathrm{kg} \text { body mass })^{-1} ; \mathrm{D} 10$, diabetic $+10 \mathrm{mg}$ vildagliptin $\cdot(\mathrm{kg} \text { body mass })^{-1}$.

Data are presented as mean \pm standard deviation $(n=8)$.

${ }^{\mathrm{a}}$ In the same row indicate statistically significant differences between C and D, D and D5, D and D10 ( $p \leq 0.05$ ).

${ }^{\mathrm{b}}$ Represents difference between D X D5.

${ }^{\mathrm{c}}$ Represents difference between D X D10.

${ }^{\mathrm{d}}$ Represents difference between C X D5.

${ }^{\mathrm{e}}$ Represents difference between $\mathrm{C}$ and D10 as determined by Student $\mathrm{t}$ test.

groups (D, D5 and D10) compared to the control groups (C, C5 and C10). Animals in the diabetic groups also showed increased final blood glucose levels when compared to animals in the control groups. Treatment with vildagliptin at 5 and $10 \mathrm{mg} / \mathrm{kg}$ failed to improve the glycemic profile of these animals, although treatment reduced blood glucose. Animals with type 1 diabetes showed a significant decrease in serum insulin compared to control animals (Table 1). Treatment with vildagliptin significantly increased insulin levels in the diabetic animals, but these values were still below the values shown in the control animals.

\section{Assessment of Redox Status in Pancreatic Tissue}

Oxidative stress markers. To measure oxidative stress markers in pancreatic tissue, we evaluated oxidative damage to proteins and lipids. Specifically, we analyzed carbonylated protein and TBARS. A significant increase in the concentration of carbonylated protein was observed

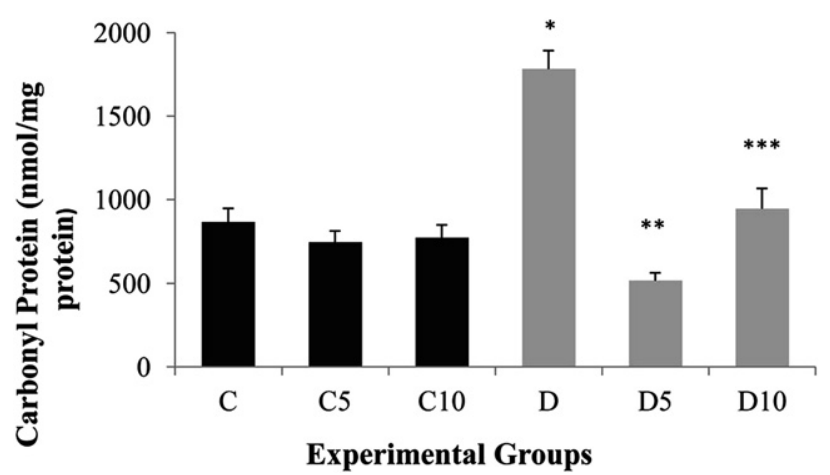

Figure 1. Data are presented as the mean $\pm \operatorname{SEM}(n=8)$. C, control (untreated); $\mathrm{C} 5$, control $+5 \mathrm{mg}$ vildagliptin $\cdot(\mathrm{kg} \text { body mass })^{-1} ; \mathrm{C} 10$, control $10 \mathrm{mg}$ vildagliptin $\cdot(\mathrm{kg} \text { bodymass })^{-1}$; D, diabetic; D5, diabetic + $5 \mathrm{mg}$ vildagliptin $\cdot(\mathrm{kg} \text { body mass })^{-1} ; \mathrm{D} 10$, diabetic $+10 \mathrm{mg}$ vildagliptin. $(\mathrm{kg} \text { body mass })^{-1}$. Statistically significant differences $(p \leq 0.05)$ are between the following groups: (*) C and D; (**) D and D5; (**) D and D10. in the pancreas of diabetic animals compared to controls (Figure 1). Diabetic animals treated with 5 and $10 \mathrm{mg} / \mathrm{kg}$ of vildagliptin showed a reduction in the concentration of carbonylated protein compared to untreated diabetic animals. Additionally, a significant increase in the concentration of TBARS was observed in diabetic animals compared to control animals (Figure 2). Vildagliptin treatment at $5 \mathrm{mg} / \mathrm{kg}$ was able to reverse the lipid peroxidation in this tissue.

Antioxidant status. To measure antioxidant status in pancreatic tissue, we evaluated the activity of total superoxide dismutase (SOD) and catalase (CAT). Diabetic animals exhibited a significant decrease in catalase activity compared to controls (Figure 3). However, vildagliptin was able to significantly increase catalase activity in diabetic animals compared to untreated diabetic animals. Surprisingly, diabetic animals exhibited a significant increase in SOD activity compared to controls, and diabetic animals

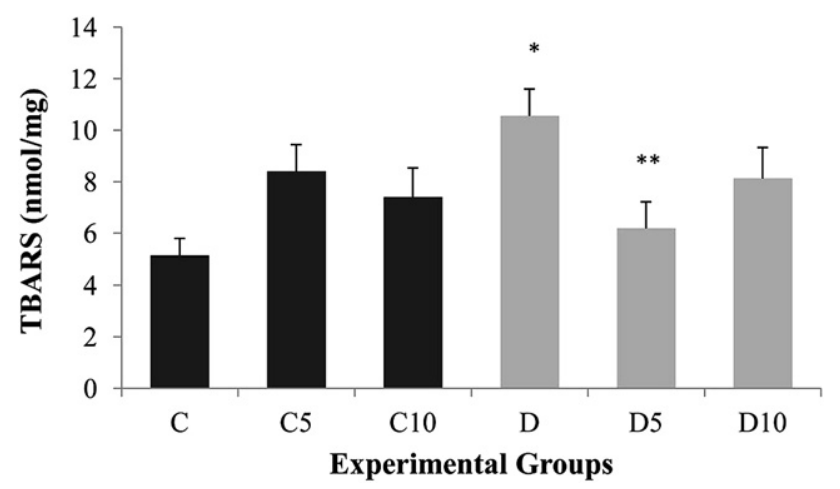

Figure 2. Data are presented as the mean $\pm \operatorname{SEM}(n=8)$. C, control (untreated); $\mathrm{C} 5$, control $+5 \mathrm{mg}$ vildagliptin $\cdot(\mathrm{kg} \text { body mass })^{-1} ; \mathrm{C} 10$, control $10 \mathrm{mg}$ vildagliptin $\cdot(\mathrm{kg} \text { body mass })^{-1}$; D, diabetic; D5, diabetic $+5 \mathrm{mg}$ vildagliptin $\cdot(\mathrm{kg} \text { body mass })^{-1} ;$ D10, diabetic $+10 \mathrm{mg}$ vildagliptin $\cdot(\mathrm{kg} \text { body mass })^{-1}$. Statistically significant differences $(p$ $\leq 0.05)$ are between the following groups: $(*) \mathrm{C}$ and $\mathrm{D} ;(* *) \mathrm{D}$ and D5. 


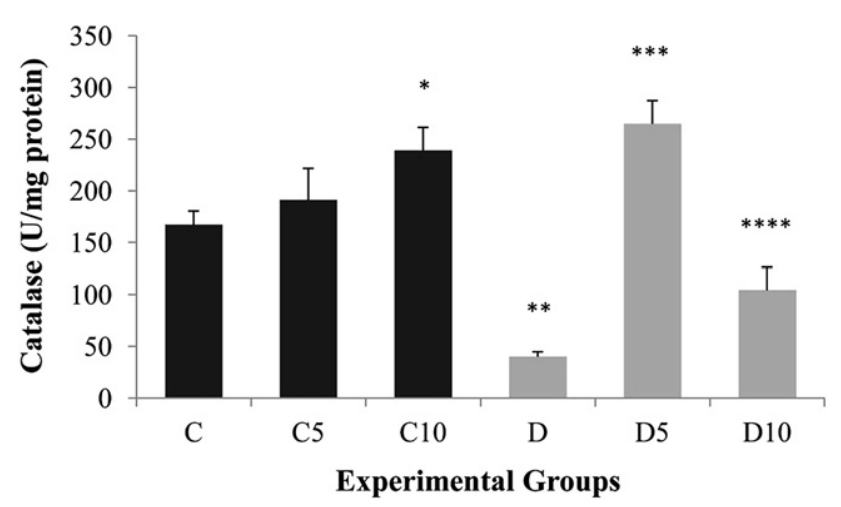

Figure 3. Data are presented as the mean \pm SEM $(n=8)$. C, control (untreated); $\mathrm{C} 5$, control $+5 \mathrm{mg}$ vildagliptin $\cdot(\mathrm{kg} \text { body mass })^{-1} ; \mathrm{C} 10$, control $10 \mathrm{mg}$ vildagliptin $\cdot(\mathrm{kg} \text { body mass })^{-1} ; \mathrm{D}$, diabetic; $\mathrm{D} 5$, diabetic $+5 \mathrm{mg}$ vildagliptin $\cdot(\mathrm{kg} \text { body mass })^{-1} ; \mathrm{D} 10$, diabetic $+10 \mathrm{mg}$ vildagliptin $\cdot(\mathrm{kg}$ body mass $)^{-1}$. Statistically significant differences $(p \leq 0.05)$ are between the following groups: (*) C and C10; (**) C and D; (**) D and D5.

treated with 5 and $10 \mathrm{mg} / \mathrm{kg}$ vildagliptin showed a dosedependent increase in SOD activity (Figure 4).

\section{Evaluation of the Relationship Between SOD and CAT Activities}

We conducted a joint assessment of SOD and CAT activity. For this experiment, we analyzed the percentage of activation or inhibition of these enzymes in the pancreas from treated or untreated diabetic rats. Increased activity of SOD in the pancreas from diabetic rats was accompanied by decreased CAT activity (Figure 5). However, treatment with vildagliptin increased both SOD and CAT activities, suggesting a balance between SOD and CAT activity.

\section{Histological Evaluation}

General histological pictures of the pancreas from all groups did not show macroscopic or microscopic

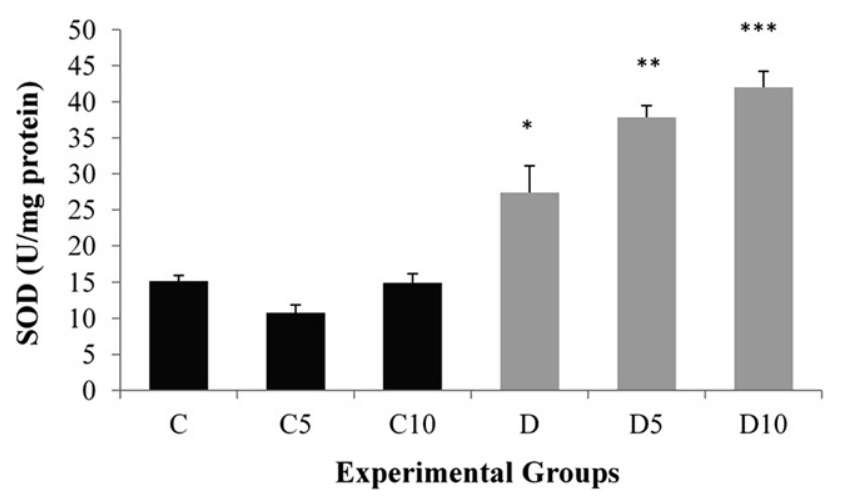

Figure 4. Data are presented as the mean $\pm \operatorname{SEM}(n=8)$. C, control (untreated); $\mathrm{C} 5$, control $+5 \mathrm{mg}$ vildagliptin $\cdot(\mathrm{kg} \text { body mass })^{-1} ; \mathrm{C} 10$, control $10 \mathrm{mg}$ vildagliptin. $(\mathrm{kg} \text { body mass })^{-1} ; \mathrm{D}$, diabetic; D5, diabetic $+5 \mathrm{mg}$ vildagliptin $\cdot(\mathrm{kg} \text { body mass })^{-1} ;$ D10, diabetic $+10 \mathrm{mg}$ vildagliptin $\cdot(\mathrm{kg} \text { body mass })^{-1}$. Statistically significant differences $(p$ $\leq 0.05)$ are between the following groups: (*) C and D; (**) D and D5; (***) D and D10.

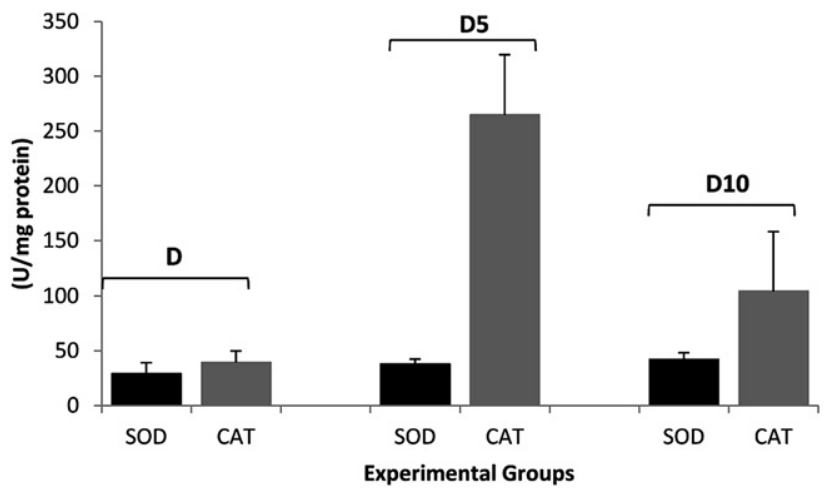

Figure 5. Data are presented as the mean $\pm \operatorname{SEM}(n=8)$. D, diabetic; D5, diabetic $+5 \mathrm{mg}$ vildagliptin $\cdot(\mathrm{kg} \text { body mass })^{-1} ; \mathrm{D} 10$, diabetic $+10 \mathrm{mg}$ vildagliptin $\cdot(\mathrm{kg} \text { body mass })^{-1}$; SOD, superoxide dismutase; CAT, catalase.

morphological and staining alterations. Additionally, signals of pancreatitis and other necrotic and degenerative pancreatic diseases were not observed. Morphometrically, the number of pancreatic islets was decreased in the diabetic group. However, vildagliptin treatment at $5 \mathrm{mg} / \mathrm{kg}$ maintained islets in the diabetic groups in numbers similar to their respective controls (Figure 6 and Figure 7). Due to the protective effect of treatment on endocrine areas of the pancreas, we evaluated the pancreatic cell populations within the islets. Diabetic animals showed a significant reduction in the number of pancreatic $\beta$-cells. Treatment with vildagliptin maintained $\beta$-cells in diabetic animals in numbers similar to those of control animals (Figure 8 and Figure 9). No differences in the populations of alpha cells within the islets were observed (results not shown).

\section{Discussion}

DPP-IV is a ubiquitous serine protease that rapidly cleaves and inactivates GIP and GLP-1 in vivo. It has been shown to increase circulating active incretin levels, thus increasing the effective concentration of these peptides that reaches the target tissues $(9,36,37)$. Dipeptidyl peptidase-4 inhibitors alone or in combination with other therapies are being promoted for the treatment of type 2 diabetes, but little is known about the potential benefits of these inhibitors in type 1 diabetes (38). Pospisilik et al. (2) showed that long-term DPP-IVi treatment of STZ rats improves glucose tolerance, enhances pancreatic insulin content, and stimulates survival of pancreatic $\beta$-cells. However, mechanisms responsible for preserving $\beta$-cells during treatment with DPP-IVi in an experimental model of type 1 diabetes have not been elucidated. Recently, oxidative stress has been reported to be responsible, to a certain extent, for $\beta$-cell dysfunction caused by glucose toxicity (39). Therefore, the aim of this study was to investigate the possible effects of DPP-IVi as a promoter in modulating the oxidant/antioxidant balance and preservation of $\beta$-cells in the pancreas of rats with type 1 diabetes. Accordingly, we conducted 

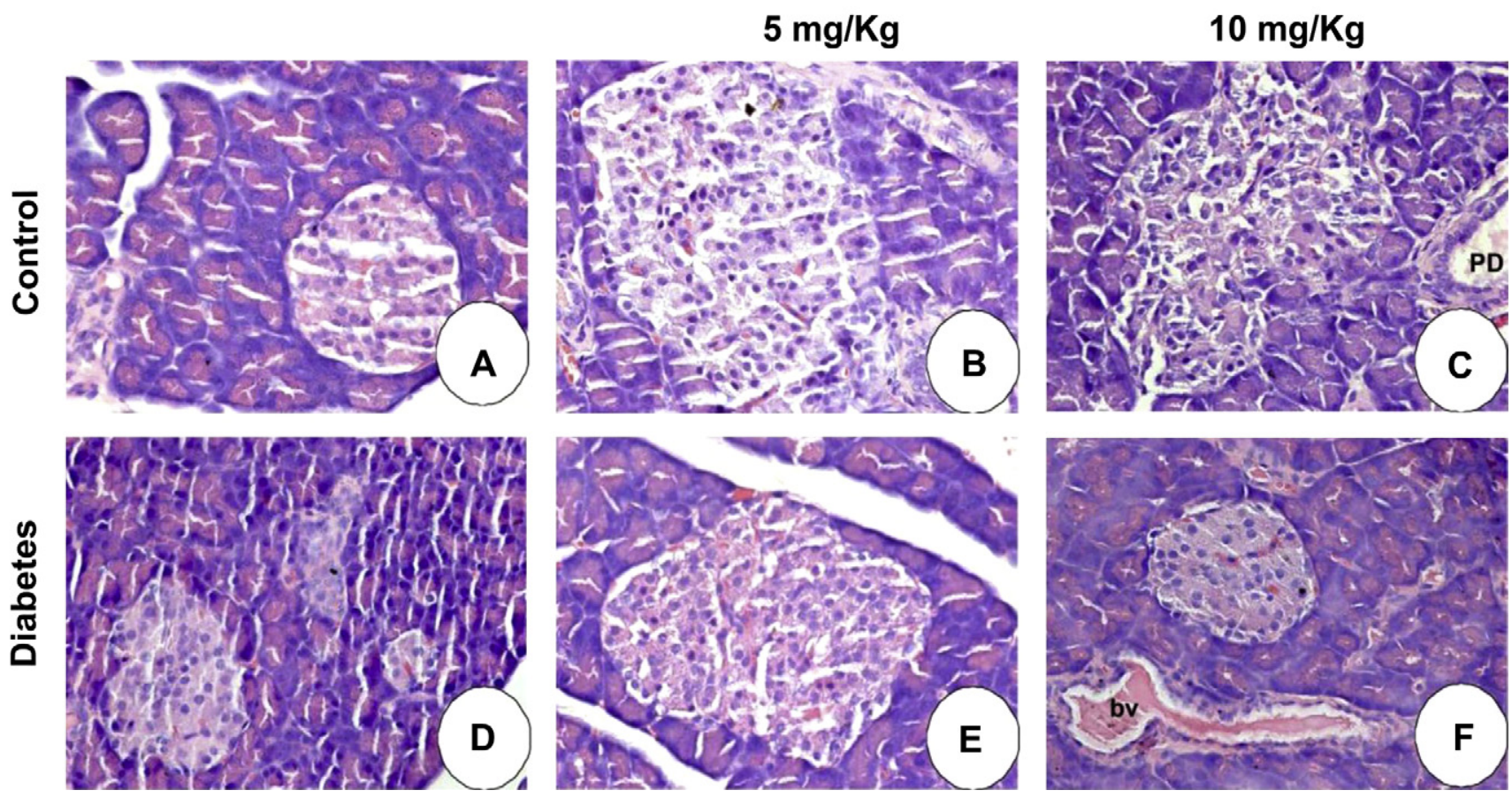

Figure 6. Histological analyses of pancreas in nondiabetic and diabetic animals treated with vildagliptin. Histological photomicrography of pancreas. (A) Normal histological aspect of the control group. (B) Control $+5 \mathrm{mg} / \mathrm{kg}$ vildagliptin. (C) Control $+10 \mathrm{mg} / \mathrm{kg}$ vildagliptin. (D) Diabetic, untreated diabetic group. (E) Diabetic $+5 \mathrm{mg} / \mathrm{kg}$ vildagliptin. (F) Diabetic $+10 \mathrm{mg} / \mathrm{kg}$ vildagliptin. bv, blood vessel, PD, pancreatic duct. Hematoxylin \& eosin staining, magnification $\times 440$.

a comparative study between two concentrations of vildagliptin DPP-IVi: $5 \mathrm{mg} / \mathrm{kg}$ and $10 \mathrm{mg} / \mathrm{kg}$.

STZ-induced diabetes was characterized by a severe loss in body weight, which has also been reported by other investigators (40). The decrease in body weight in diabetic rats may indicate loss or degradation of structural proteins, which have been reported to contribute to body weight (41). The present study showed that vildagliptin did not prevent weight loss. Moreover, vildagliptin was unable to alter the

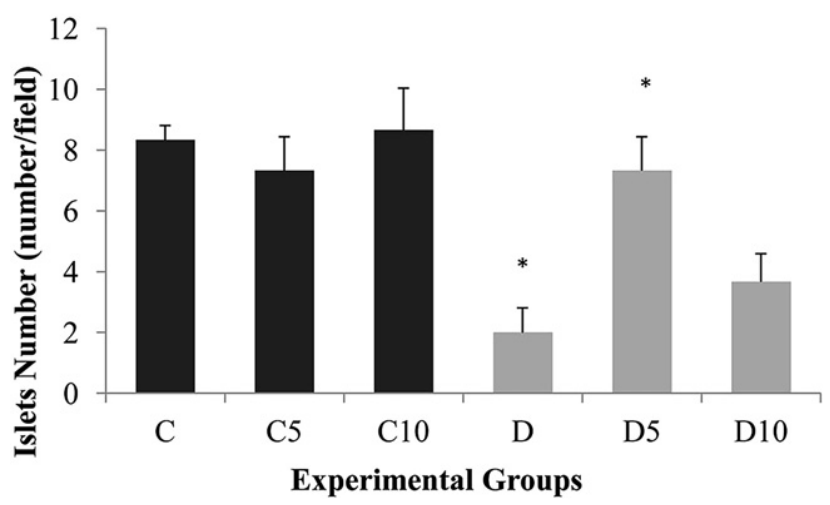

Figure 7. Data are presented as the mean $\pm \operatorname{SEM}(n=8)$. C, control (untreated); C5, control $+5 \mathrm{mg}$ vildagliptin $\cdot\left(\mathrm{kg}\right.$ body mass) ${ }^{-1}$; $\mathrm{C} 10$, control $10 \mathrm{mg}$ vildagliptin $\cdot(\mathrm{kg} \text { body mass })^{-1}$; D, diabetic; D5, diabetic $+5 \mathrm{mg}$ vildagliptin $\cdot(\mathrm{kg} \text { body mass })^{-1} ; \mathrm{D} 10$, diabetic $+10 \mathrm{mg}$ vildagliptin $\cdot(\mathrm{kg} \text { body mass })^{-1}$. Statistically significant differences $(p$ $\leq 0.05)$ are between the following groups: $(*) \mathrm{C}$ and $\mathrm{D} ;\left(^{* *}\right) \mathrm{D}$ and D5. plasma glucose levels of diabetic animals (Table 1). Interestingly, we found a significant increase in plasma insulin in diabetic rats treated with vildagliptin compared to untreated rats, but the concentration of insulin in these animals was $\sim 40 \%$ lower when compared to control animals. Moreover, Jin et al. (27) reported that treatment with vildagliptin partially improves the reduction in insulin levels in STZ-diabetic rats. This outcome occurs in spite of unaffected fasting glucose and glycated hemoglobin (HbA1c) levels but is associated with an increase in GLP1 plasma levels.

Lipid peroxidation of unsaturated fatty acids is frequently used as an indicator of increased oxidative stress and subsequent oxidative damage (42) and is characteristic of chronic diabetes (43). Lipid peroxidation impairs cell membrane fluidity and alters activity of membrane-bound enzymes and receptors, resulting in membrane malfunction (44). The high level of the lipid peroxidation marker TBARS in diabetic rats is a reflection of insufficient antioxidant defenses in combating ROS-mediated damage. Our data show that the pancreas of diabetic animals has increased oxidative damage, exemplified by the increased concentration of TBARS. Several studies also showed an increase in the concentration of TBARS in the pancreatic tissue of diabetic rats $(43,45,46)$. However, animals treated with $5 \mathrm{mg} / \mathrm{kg}$ vildagliptin showed significantly decreased concentrations of TBARs compared to untreated diabetic animals (Figure 2). Davidson et al. showed that treating 

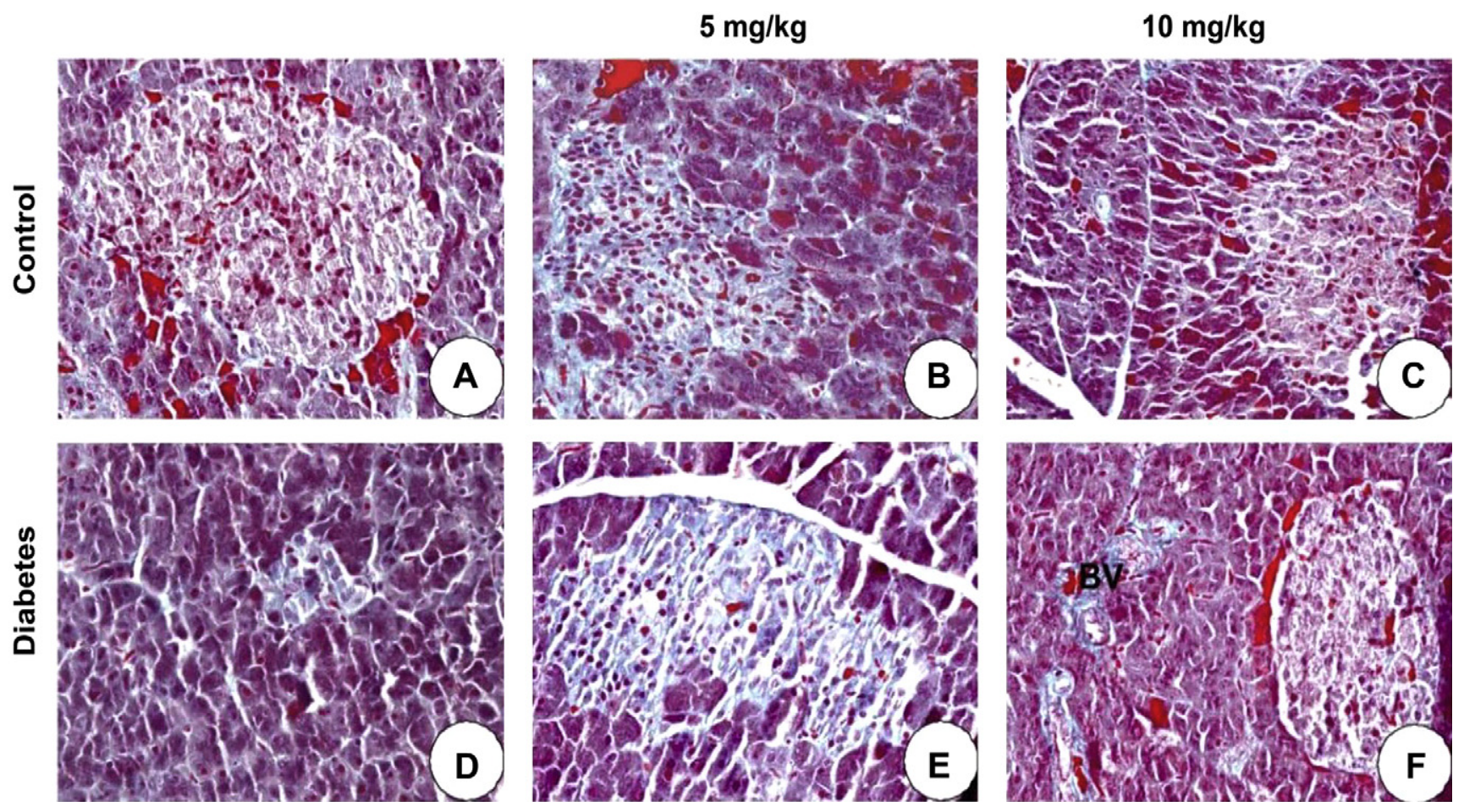

Figure 8. Photomicrographs of histological pancreas sections. Diabetic animals diabetic (D) show a decrease of pancreatic beta cells (arrows) in relation to its control (Figure 7). There were no changes in the number of alpha cells. Gomori trichrome. $\times 440$. BV, blood vessel.

diabetic rats with alogliptin (DPP-4i) at $10-20 \mathrm{mg} / \mathrm{kg}$ concentrations per rat per day also lowered serum TBARS, but the difference was not significant compared to untreated diabetic rats. Protein carbonyl contents, reflecting oxidative protein damage, were observed in the pancreas of diabetic animals. Vildagliptin at 5 and $10 \mathrm{mg} / \mathrm{kg}$ was effective in reducing the concentration of carbonylated protein in diabetic animals (Figure 1). Analyzing the results together, we suggest that vildagliptin was able to modulate oxidative

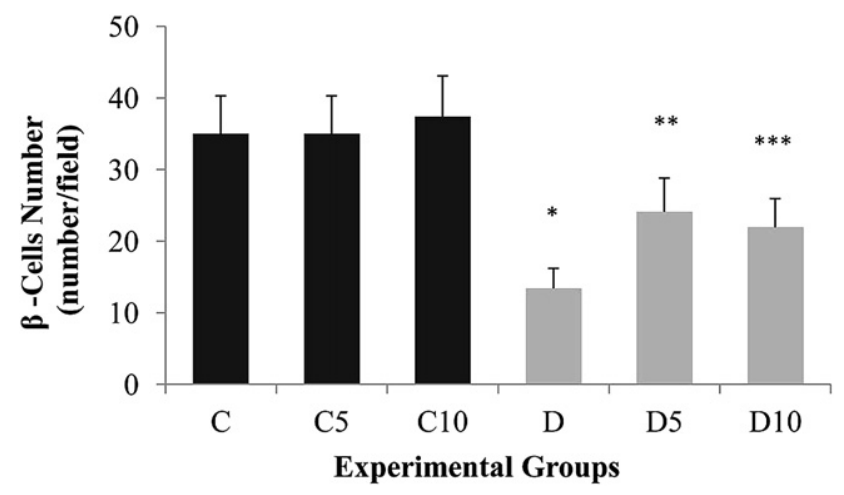

Figure 9. Data are presented as the mean $\pm \operatorname{SEM}(n=8)$. C, control (untreated); $\mathrm{C} 5$, control $+5 \mathrm{mg}$ vildagliptin $\cdot(\mathrm{kg} \text { body mass })^{-1} ; \mathrm{C} 10$, control $10 \mathrm{mg}$ vildagliptin $\cdot(\mathrm{kg} \text { body mass })^{-1}$; D, diabetic; D5, diabetic $+5 \mathrm{mg}$ vildagliptin $\cdot(\mathrm{kg} \text { body mass })^{-1}$; D10, diabetic $+10 \mathrm{mg}$ vildagliptin $\cdot(\mathrm{kg} \text { body mass })^{-1}$. Statistically significant differences $(p$ $\leq 0.05$ ) are between the following groups: (*) C and D; (**) D and D5 $(* * *) \mathrm{D}$ and D10. damage, as exemplified by the lower levels of TBARS and carbonylated protein.

Pancreatic $\beta$-cells are highly prone to oxidative stress and damage because they have low expression and activity of antioxidant enzymes, which are the first line of defense against oxidative insult (47). SOD and CAT enzymes constitute the first line of cellular antioxidant defense. SOD is one of the most important enzymes in the enzymatic antioxidant defense system and catalyzes the dismutation of superoxide radicals to produce $\mathrm{H}_{2} \mathrm{O}_{2}$ and molecular oxygen (48). In this study we found that the activity of SOD was upregulated in the diabetic pancreas. Although SOD is an antioxidant enzyme, some studies have suggested that its overexpression is, in fact, harmful to cells (49). The toxic effect of ROS observed in many cells with overexpressed SOD has been linked to elevated levels of $\mathrm{H}_{2} \mathrm{O}_{2}$ and accompanying oxidative damage following hydroxyl radical formation (50). The implication for SOD upregulation is the high turnover of $\mathrm{H}_{2} \mathrm{O}_{2}$. Because CAT, which inactivates $\mathrm{H}_{2} \mathrm{O}_{2}$, is an endogenous enzyme and needs to be replenished, the continuous formation of $\mathrm{H}_{2} \mathrm{O}_{2}$ may overwhelm this enzyme. Moreover, $\mathrm{O}_{2}{ }^{\bullet}$ is reported to inhibit CAT directly (51); thus, ROS could cause reduced CAT activity in the diabetic rats. The enhanced activity of SOD and reduced CAT activity may generate excessive $\mathrm{H}_{2} \mathrm{O}_{2}$, which could increase to other ROS such as hydroxyl radicals $(49,50)$, thus contributing to the increased oxidative stress in the pancreas of diabetic rats. 
For the first time, our group describes the increase in SOD activity induced by treatment with vildagliptin accompanied by an increase in catalase activity (Figure 3 and Figure 4), which could minimize the deleterious effects of $\mathrm{H}_{2} \mathrm{O}_{2}$ in the pancreas of diabetic rats. Notably, the likely mechanism responsible for the increased catalase activity in animals treated with vildagliptin is independent of the concentration of hydrogen peroxide, as SOD activity is also increased in the pancreas of rats treated with vildagliptin. Moreover, treatment with $5 \mathrm{mg} / \mathrm{kg}$ vildagliptin is more effective in maintaining the redox balance of the pancreatic $\beta$-cells when compared to treatment with $10 \mathrm{mg} / \mathrm{kg}$ (Figure 5). This study also performed tests with $50 \mathrm{mg} / \mathrm{kg}$ vildagliptin. However, most animals treated with $50 \mathrm{mg} /$ $\mathrm{kg}$ died during treatment or showed a higher level of stress as measured by protein carbonyl and TBARS (data not shown). Thus, we believe that higher doses of vildagliptin may be toxic to the animal.

Recent studies in rodent models of diabetes suggest that DPP-IVi have the ability to increase islet mass and preserve $\beta$-cell function by immediate reactivation of $\beta$-cell glucose competence as well as enhanced beta-cell proliferation and neogenesis and promotion of $\beta$-cell survival (52). $\beta$-cell dysfunction progresses to a reduction in $\beta$-cell mass, which is caused by $\beta$-cell death in diabetic patients $(53,54)$. We observed a reduction in the number of islet cells in the pancreas of diabetic rats accompanied by a decreased number of $\beta$-cells, whereas islets and $\beta$-cell numbers were significantly increased in diabetic rats treated with vildagliptin compared to untreated rats (Figure 6 and Figure 8). Notably, treatment with $5 \mathrm{mg} / \mathrm{kg}$ vildagliptin was more effective in reducing oxidative stress in pancreatic tissue, and this reduction of stress can allow for greater preservation of $\beta$-cells.

Cho et al. (55) showed that DA-1229, a novel DPP-IVi, ameliorated established diabetes after STZ treatment by increasing $\beta$-cell mass, which could be explained by increased $\beta$-cell regeneration and enhanced $\beta$-cell neogenesis. Small changes in $\beta$-cell mass could be critical in the regulation of the release of insulin when $\beta$-cell mass is critically compromised. This phenomenon could be the reason why an increase in $\beta$-cell mass by vildagliptin led to an improvement of the plasma insulin level. This study had several limitations. First, the effect of the DPP-IVi on glucose metabolism was not completely excluded. Second, molecular research should be performed to further investigate the mechanisms of cell signaling related to the effect of preserving $\beta$-cells, such as the evaluation of the activity of caspases in the pancreas. In addition, future studies should consider further evaluation of the regulation of pro-inflammatory cytokines and anti-inflammatory pancreatic tissue that may lead to a better understanding of the mechanisms responsible for the amelioration of $\beta$-cell destruction.
In conclusion, this study demonstrated that $5 \mathrm{mg} / \mathrm{kg}$ vildagliptin has a remarkable antioxidant effect, leads to an increase in endogenous antioxidant defense capacity and, consequently, reduces formation of ROS as demonstrated indirectly by decreased levels of TBARS and carbonyl protein in pancreatic tissue.

Moreover, by increasing the circulating levels of incretins, vildagliptin led to an increase in serum insulin levels, although this increase was not accompanied by a decrease in blood glucose. In addition to minimizing the deleterious effects of oxidative stress in diabetes and improving insulin levels, the analysis of pancreatic histology showed that vildagliptin was effective in ameliorate the destruction of $\beta$-cells in animals with type 1 diabetes. However, further studies are necessary to elucidate the mechanisms induced by vildagliptin, which are responsible for its antioxidant effect.

\section{References}

1. Atkinson M, Eisenbarth G. Type 1 diabetes: new perspectives on disease pathogenesis and treatment. Lancet 2001;358:221-229.

2. Pospisilik JA, Martin J, Doty T, et al. Dipeptidyl peptidase IV inhibitor treatment stimulates $\beta$-cell survival and islet neogenesis in streptozotocin-induced diabetic rats. Diabetes 2003;52:741-750.

3. Brubaker PL, Drucker DJ. Minireview: glucagon-like peptides regulate cell proliferation and apoptosis in the pancreas, gut, and central nervous system. Endocrinology 2004;145:2653-2659.

4. Drucker DJ. The biology of incretin hormones. Cell Metab 2006;3: 153-165.

5. Ehses JA, Casilla VR, Doty T, et al. Glucose-dependent insulinotropic polypeptide promotes beta-(INS-1) cell survival via cyclic adenosine monophosphate-mediated caspase-3 inhibition and regulation of p38 mitogenactivated protein kinase. Endocrinology 2003; 144:4433-4445.

6. Kim SJ, Winter K, Nian C, et al. Glucose dependent insulinotropic polypeptide (GIP) stimulation of pancreatic beta-cell survival is dependent upon phosphatidylinositol 3-kinase (PI3K)/protein kinase B (PKB) signaling, inactivation of the forkhead transcription factor Foxo1, and downregulation of bax expression. J Biol Chem 2005;280:22297-22307.

7. Kim SJ, Nian C, Widenmaier S, et al. Glucose-dependent insulinotropic polypeptide (GIP) mediated up-regulation of $\beta$-cell antiapoptotic Bcl-2 gene expression is coordinated by cAMP-response element binding protein (CREB) and cAMP-responsive CREB coactivator 2 (TORC2). Mol Cell Biol 2008;28:1644-1656.

8. Mentlein R, Gallwitz B, Schmidt WE. Dipeptidyl-peptidase IV hydrolyses gastric inhibitory polypeptide, glucagon-like peptide-1(7-36) amide, peptide histidine methionine and is responsible for their degradation in human serum. Eur J Biochem 1993;214:829-835.

9. Kieffer TJ, McIntosh CHS, Pederson RA. Degradation of glucosedependent insulinotropic polypeptide and truncated glucagon-like peptide 1 in vitro and in vivo by dipeptidyl peptidase IV. Endocrinology 1995; 136:3585-3596.

10. Deacon CF, Johnsen AH, Holst JJ. Degradation of glucagon-like peptide-1 by human plasma in vitro yields an $\mathrm{N}$-terminally truncated peptide that is a major endogenous metabolite in vivo. J Clin Endocrinol Metab 1995;80:952-957.

11. De Meester I, Korom S, Van Damme J, et al. CD26, let it cut or cut it down. Immunol Today 1999;20:367-375.

12. Pospisilik JA, Ehses JA, Doty T, et al. Dipeptidyl peptidase IV inhibition in animal models of diabetes. Adv Exp Med Biol 2003;524:281-291.

13. Miyagawa J, Miuchi M, Namba M. Incretin-based therapy in patients with type 1 diabetes mellitus. Nihon Rinsho 2001;69:923-929. 
14. Mu J, Woods J, Zhou YP, et al. Chronic inhibition of dipeptidyl peptidase4 with a sitagliptin analog preserves pancreatic $\beta$-cell mass and function in a rodent model of type 2 diabetes. Diabetes 2006;55:1695-1704.

15. Kim SJ, Nian C, Doudet DJ, et al. Inhibition of dipeptidyl peptidase IV with sitagliptin (MK0431) prolongs islet graft survival in streptozotocin-induced diabetic mice. Diabetes 2008;57:1331-1339.

16. Sudre B, Broqua P, White RB, et al. Chronic inhibition of circulating dipeptidyl peptidase IV by FE 999011 delays the occurrence of diabetes in male zucker diabetic fatty rats. Diabetes 2002;51:1461-1469.

17. Poungvarin N, Lee JK, Yechoor VK, et al. Carbohydrate response element-binding protein (ChREBP) plays a pivotal role in beta cell glucotoxicity. Diabetologia 2012;55:1783-1796.

18. Unger RH, Grundy S. Hyperglycaemia as an inducer as well as a consequence of impaired islet cell function and insulin resistance: implications for the management of diabetes. Diabetologia 1985;28:119-121.

19. Leahy JL, Bonner-Weir S, Weir GC. Beta-cell dysfunction induced by chronic hyperglycemia. Current ideas on mechanism of impaired glucose-induced insulin secretion. Diabetes Care 1992;15:442-455.

20. Kaneto H, Katakami N, Kawamori D, et al. Involvement of oxidative stress in the pathogenesis of diabetes. Antioxid Redox Signal 2007;9: 355-366.

21. Piro S, Anello M, Di PC, et al. Chronic exposure to free fatty acids or high glucose induces apoptosis in rat pancreatic islets: possible role of oxidative stress. Metabolism 2002;51:1340-1347.

22. Cerf ME. High-fat diet modulation of glucose sensing in beta-cell. Med Sci Monit 2007;13:RA12-RA17.

23. Ammon HP, Bumiller G, Düppenbecker H, et al. Pentose phosphate shunt, pyridine nucleotides, glutathione, and insulin secretion of fetal islets. Am J Physiol 1983;244:E354-E360.

24. Lenzen S, Drinkgern J, Tiedge M. Low antioxidant enzyme gene expression in pancreatic islets compared with various other mouse tissues. Free Radic Biol Med 1996;20:463-466.

25. Colégio Brasileiro de Experimentação Animal. Princípios éticos na experimentação animal do Colégio Brasileiro de Experimentação Animal. São Paulo: COBEA; 1991.

26. Akarte AS, Srinivasan BP, Gandhi S. Relationships between the islets blood flow, nitric oxide, insulin, and cytosolic calcium in rat pancreatic islets: Effects of DPP-IV inhibitor vildagliptin. Eur J Pharmaceut Sci 2012;45:546-551.

27. Jin HY, Liu WJ, Park JH, et al. Effect of dipeptidyl peptidase-IV (DPPIV) inhibitor (Vildagliptin) on peripheral nerves in streptozotocininduced diabetic rats. Arch Med Res 2010;40:536-544.

28. Akarte AS, Srinivasan BP, Gandhi S, et al. Chronic DPP-IV inhibition with PKF-275-055 attenuates inflammation and improves gene expressions responsible for insulin secretion in streptozotocin induced diabetic rats. Eur J Pharmaceut Sci 2012;47:456-463.

29. Burkey BF, Li X, Bolognese L, et al. Acute and chronic effects of the incretin enhancer vildagliptin in insulin-resistant rats. J Pharmacol Exp Ther 2005;315:688-695.

30. Akarte AS, Srinivasan BP, Gandhi S. Vildagliptin selectively ameliorates GLP-1, GLUT4, SREBP-1c mRNA levels and stimulates $\beta$-cell proliferation resulting in improved glucose homeostasis in rats with streptozotocin-induced diabetes. J Diabetes Complic 2012;26:266-274.

31. Matsui T, Nishino Y, Takeuchi M, et al. Vildagliptin blocks vascular injury in thoracic aorta of diabetic rats by suppressing advanced glycation end product-receptor axis. Pharmacol Res 2011;63:383-388.

32. Lenzen S. The mechanisms of alloxan and streptozotocin-induced diabetes. Diabetologia 2008;51:216-226.

33. Aebi H. Catalase in vitro. Methods Enzymol 1984;105:121-126.

34. Beuge JA, Aust SD. Microsomal lipid peroxidation. Methods Enzymol 1978;52:302-310.
35. Levine RL, Williams JA, Stadtman ER, et al. Carbonyl assays for determination of oxidatively modified proteins. Methods Enzymol 1994;233:346-357.

36. Pauly RP, Rosche F, Wermann M, et al. Investigation of glucosedependent insulinotropic polypeptide-(1-42) and glucagon-like peptide-1-(7-36) degradation in vitro by dipeptidyl peptidase IV using matrix-assisted laser desorption/ionization-time of flight mass spectrometry. A novel kinetic approach. J Biol Chem 1996;271:23222-23229.

37. Deacon CF, Nauck MA, Meier J, et al. Degradation of endogenous and exogenous gastric inhibitory polypeptide in healthy and in type 2 diabetic subjects as revealed using a new assay for the intact peptide. J Clin Endocrinol Metab 2000;85:3575-3581.

38. Davidson JA. Incorporating incretin-based therapies into clinical practice: differences between glucagon-like peptide 1 receptor agonists and dipeptidyl peptidase 4 inhibitors. Mayo Clin Proc 2010;85:S27-S37.

39. Evans JL, Goldfine ID, Maddux BA, et al. Are oxidative stressactivated signaling pathways mediators of insulin resistance and $\beta$ cell dysfunction? Diabetes 2003;52:1-8.

40. Chen V, Ianuzzo CD. Dosage effect of streptozotocin on rat tissue enzyme activities and glycogen concentration. Can J Physiol Pharmacol 1982;60:1251-1256.

41. Rajkumar L, Govindarajulu P. Increased degradation of dermal collagen in diabetic rats. Indian J Exp Biol 1991;129:1081-1083.

42. Hauggard N. Cellular mechanism of oxygen toxicity. Physiol Rev 1968;48:311-373.

43. Bhandari U, Jain N, Pillai KK. Further studies on antioxidant potential and protection of pancreatic beta-cells by Embelia ribes in experimental diabetes. Exp Diabetes Res 2007;2007:15803.

44. Halliwell B. Lipid peroxidation, antioxidants and cardiovascular disease: how should we move forward? Cardiovasc Res 2000;47:410-448.

45. Dahech I, Belghith KS, Hamden K, et al. Antidiabetic activity of levan polysaccharide in alloxan-induced diabetic rats. Int J Biol Macromol 2011;49:742-746.

46. Babujanarthanam R, Kavitha P, Mahadeva Rao US, et al. Quercitrin a bioflavonoid improves the antioxidant status in streptozotocin: induced diabetic rat tissues. Mol Cell Biochem 2011;358:121-129.

47. Lenzen S. Oxidative stress: the vulnerable beta-cell. Biochem Soc Trans 2008;36:343-347.

48. Venarucci D, Venarucci V, Vallese A, et al. Free radicals: important cause of pathologies refer to ageing. Panminerva Med 1999;41:335-339.

49. Gardner R, Salvador A, Moradas-Ferreira P. Why does SOD overexpression sometimes enhance, sometimes decrease, hydrogen peroxide production? A minimalist explanation. Free Radic Biol Med 2002;32:1351-1357.

50. de Haan JB, Cristiano F, Iannello R, et al. Elevation in the ratio of $\mathrm{Cu} / \mathrm{Zn}$-superoxide dismutase to glutathione peroxidase activity induces features of cellular senescence and this effect is mediated by hydrogen peroxide. Hum Mol Genet 1996;5:283-292.

51. Kono Y, Fridovich I. Superoxide radical inhibits catalase. J Biol Chem 1982;257:5751-5754.

52. Portha B, Tourrel-Cuzin C, Movassat J. Activation of the GLP-1 receptor signalling pathway: a relevant strategy to repair a deficient beta-cell mass. Exp Diabetes Res 2011;2011:376509.

53. Butler AE, Janson J, Bonner-Weir S, et al. $\beta$-Cell deficit and increased $\beta$-cell apoptosis in humans with type 2 diabetes. Diabetes 2003;52:102-110

54. Mathis $\mathrm{D}$, Vence $\mathrm{L}$, Benoist C. $\beta$-Cell death during progression to diabetes. Nature 2001;414:792-798.

55. Cho JM, Jang HW, Cheon H, et al. A novel dipeptidyl peptidase IV inhibitor DA-1229 ameliorates streptozotocin-induced diabetes by increasing $\beta$-cell replication and neogenesis. Diabetes Res Clin Pract 2011;91:72-79. 